\title{
System Based Ship Design for Fast Ferry
}

\author{
Ericza Damaranda Sugita ${ }^{1}$, Wasis Dwi Aryawan ${ }^{2}$, and Rizka Arie Hutama ${ }^{3}$ \\ ${ }^{1}$ Departement of Ocean Engineering, Institut Teknologi Sepuluh Npember, Surabaya \\ ${ }^{2}$ Departement of Naval Architecture, Institut Teknologi Sepuluh Nopember, Surabaya \\ ${ }^{3}$ PT. Pertamina Trans Kontinental, Jakarta \\ e-mail: aryawanwasis@gmail.com
}

\begin{abstract}
Design is a complex process where creativity and analytical skills are needed for success. At present, the development of design methods has moved towards field practice rather than theory. The main objective of this research is to determine the design of fast ferry to transport passengers from Sorong to other coastal areas in West Papua. The method used in this fast ferry design is the System Based Ship Design (SBSD) method which uses a strategy to reduce the number of loops to find the best concept by giving greater emphasis to the analysis of functions. The design study begins with a mission statement and establishes the main function requirements. Then find the area and volume needed on each deck that is determined by using life size experiment and model test experiment to determine the initial main dimensions. Then, alternatives to be evaluated against the relevant framework conditions. The results of this study is catamaran fast ferry design with a load capacity of 100 passengers and has a speed of 40 knots. It has main dimensions of length of $40,387 \mathrm{~m}$, breadth of 11.02 meters, and draft of 1.5 meters. It is propelled by water jet propulsion and aluminium material applied.
\end{abstract}

Keywords-Fast Ferry, Life Size Experiment, Model Test Experiment, System Based Ship Design.

\section{INTRODUCTION}

$\mathrm{W}$ EST Papua is a Indonesia province which is located on the west end of Papua Island. The densely populated areas and economic centers of West Papua are generally located in coastal areas. West Papua's most dominant economy is in the tourism sector such as Raja Ampat National Park and mining companies which are scattered around Sorong City and in the Bintuni Bay area. These mining companies are multinational companies that employ thousands of employees from all over the world. For interregional transportation, the main transportation uses air and land vehicles. However, to go to other areas which are located quite far away, you have to use small planes and helicopters which are more expensive. While for land routes, it will require a much longer time due to difficult terrain.

In other parts of the world, transportation of catamaran fast ferry has been widely used to boost economic growth in a region such as Australia's Great Barrier Reef, Scandinavia, Batam-Singapore crossing [1], and Hongkong-Macau-China [2]. The use of fast ferries in Batam-Singapore, and Hong Kong-Macau-China has a characteristic that is the traffic in the waters of this area is very crowded which indicates the center of a developing economy that requires good means of transportation. Other uses of catamaran fast ferries, like on Australia's Great Barrier Reef, are used as a means of tourism, and Scandinavia for offshore exploration. It distinctive

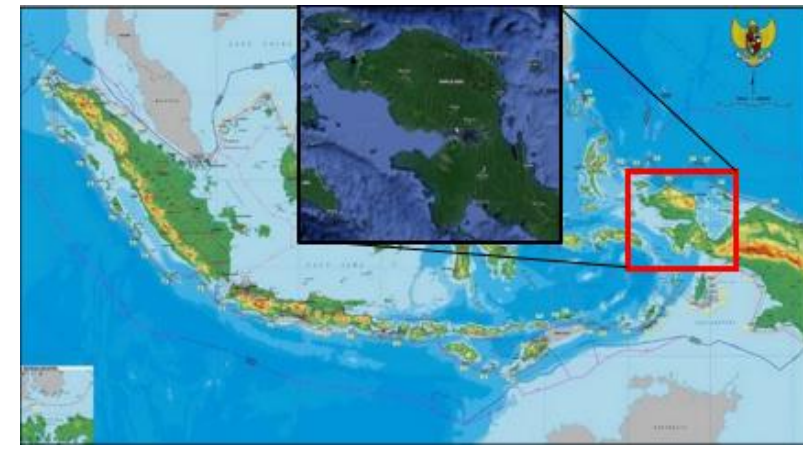

Figure 1. West Papua.

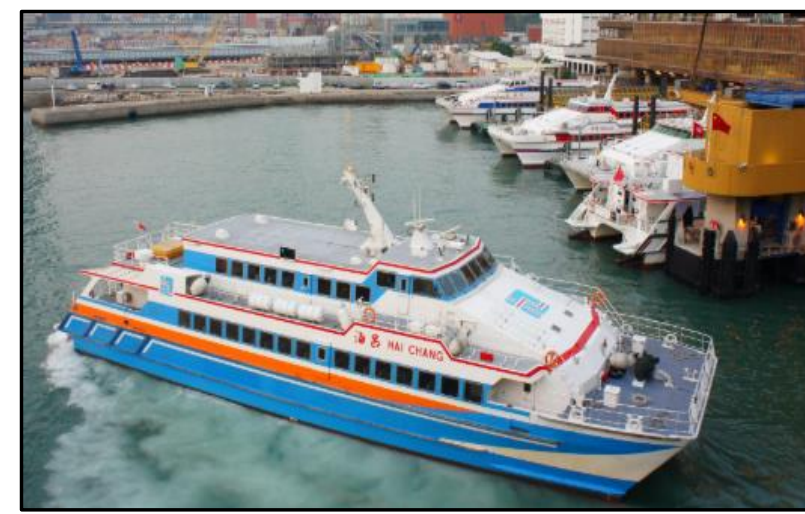

Figure 2. Catamaran in Hong-Kong.

feature is the traffic in the quiet waters of this area, because there are economic activities in an area which will require transportation facilities that can support these economic activities. Catamaran fast ferries used at these sites are designed by large aluminum catamaran vendors such as Incat, Damen or Austal. West Papua can see at Figure 1.

Based on the current condition of West Papua, a suitable transportation facility used to transport passengers from Sorong City to other coastal locations, but can reduce travel costs and cut travel time, is fast ferry. The advantages offered by the use of fast ferry compared to airplanes are cheaper travel costs with relatively the same or more cargo, and can reach directly to coastal residential areas only by approaching the waters of the area. In addition, the advantages offered by the use of fast ferr compared to land vehicles are faster times with relatively the same or more loads.

The advantages of using this fast catamaran ferry can be achieved if the ship has a good design. Design is a complex process in which creativity and analytical skills are needed for success. In this research, the method used is System Based Ship Design (SBSD) where this method uses an approach by 


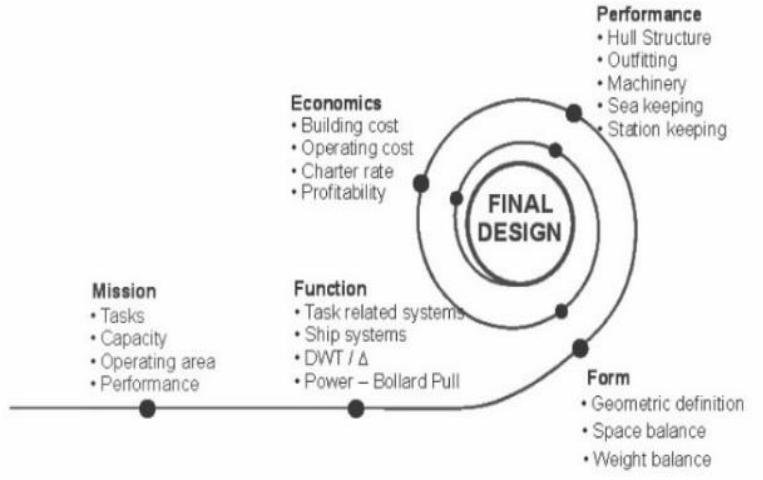

Figure 4. Design spiral describing the SBSD process.

Table 2.

First round elimination

\begin{tabular}{|c|c|c|}
\hline Sub Function & Item & Elimination Reasons \\
\hline Material & Wood & Not efficient \\
\hline \multirow[t]{2}{*}{ Propulsion } & & ble an \\
\hline & & $t$ and dangerous \\
\hline \multirow[t]{2}{*}{ Resource } & Human & Not e \\
\hline & Gas fuel & $\begin{array}{l}\text { There is no technical support and is still } \\
\text { under development in Indonesia }\end{array}$ \\
\hline Full c & Auto & $\begin{array}{l}\text { Hazardous environment and low } \\
\text { technical support on site }\end{array}$ \\
\hline
\end{tabular}

Table 3.

Second round elimination

\begin{tabular}{|c|c|c|}
\hline Sub Function & Item & Elimination Reasons \\
\hline Material & Fiberglass & $\begin{array}{l}\text { Highly flammable and does not last } \\
\text { long }\end{array}$ \\
\hline Hull & Barge & Poor hydrodynamic performance \\
\hline Propulsion & $\begin{array}{l}\text { Outboard motor } \\
\text { (propeller) }\end{array}$ & $\begin{array}{l}\text { Not suitable for fast ferry with } \\
\text { speeds above } 25 \text { knots }\end{array}$ \\
\hline Resource & Solar & $\begin{array}{l}\text { Low efficiency and low on site } \\
\text { technical support }\end{array}$ \\
\hline Full control & Remote control & $\begin{array}{l}\text { Hazardous environment and low } \\
\text { technical support on site }\end{array}$ \\
\hline
\end{tabular}

reducing the number of loops needed to find the right concept [3]. Catamaran in Hong-Kong can see at Figure 2.

\section{METHOD}

The presence of computers that have entered the world of design is becoming increasingly important as a tool for design. Levander and Erikstad [4] present a new method for ship design, the System Based Ship Design (SBSD) method which uses a strategic approach by reducing the number of loops and using bottom-up in estimating volume requirements before each drawing will be sketched. The output of the SBSD approach is a volume list, which is then combined with some data based on experience as well as some key values and important values such as the hull form. Illustration shown in Figure 4.

System-based ship design (SBSD) research previously conducted by Vestbøstad [5]. This research explains how the System Based Ship Design approach can support an efficient and innovative ship design process. This research will explore how the SBSD approach can be used in the Offshore Vessels design process, and consider how a simplified SBSD approach can support the design process of a new building by making a real concrete discussion for salespeople, designers, and clients at an early stage. The output of the SBSD
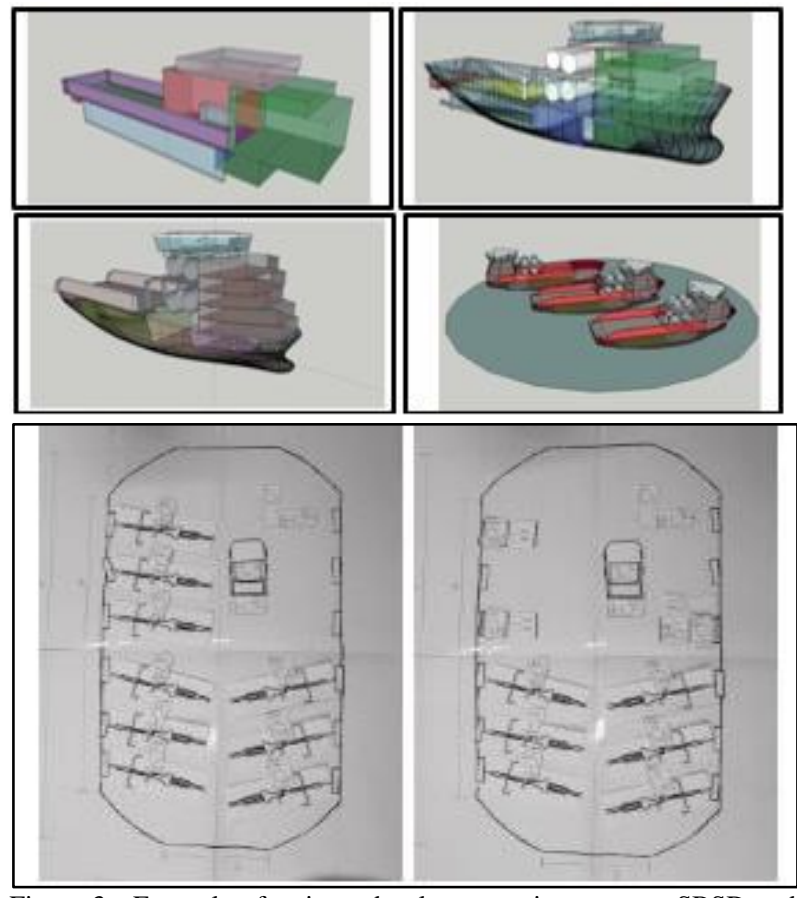

Figure 3. Example of estimated volume requirements on SBSD and SBSD life size tests.

Table 1.

Third round elimination

\begin{tabular}{cll}
\hline \hline \multicolumn{1}{c}{$\begin{array}{c}\text { Sub } \\
\text { Function }\end{array}$} & \multicolumn{1}{c}{ Item } & \multicolumn{1}{c}{ Elimination Reasons } \\
\hline Hull & Steel & $\begin{array}{l}\text { The weight and corrosion rate is } \\
\text { faster than aluminum }\end{array}$ \\
Material & Fiberglass & $\begin{array}{l}\text { Easy to burn and shorter life than } \\
\text { metal }\end{array}$ \\
Propulsion & $\begin{array}{l}\text { Inboard } \\
\text { motor } \\
\text { (propeller) }\end{array}$ & $\begin{array}{l}\text { Not suitable for fast ferry with } \\
\text { speeds above 25 knots }\end{array}$ \\
Resource & Battery & $\begin{array}{l}\text { Expensive middle age and low } \\
\text { technical support }\end{array}$ \\
\hline \hline
\end{tabular}

approach in this study is a list of the volumes needed for new buildings and the weight of each volume. The results of this study are shown inFigure 3 (a).

Other research on System Based Ship Design (SBSD) has also been conducted previously by Havdal, Torjussen, and Larssen [6]. This research also discusses the concepts for functional requirements set out from the main objectives and discussed through brainstorming sessions. The information needed will be collected to evaluate the feasibility of the concept. Evaluation will be needed after further development to limit the work to one design. Several iterations may be needed where each iteration will improve the design in accordance with the ongoing evaluation. The process of determining the main size used is to use the method of life size experiment and model size experiment, namely by way of trial and error in the arrangement of the room based on the area and volume of the load to be carried. After the main dimensions are obtained, a line plan and general plan drawing will be made. Then proceed with providing detailed information about hull design and equipment management on board. 


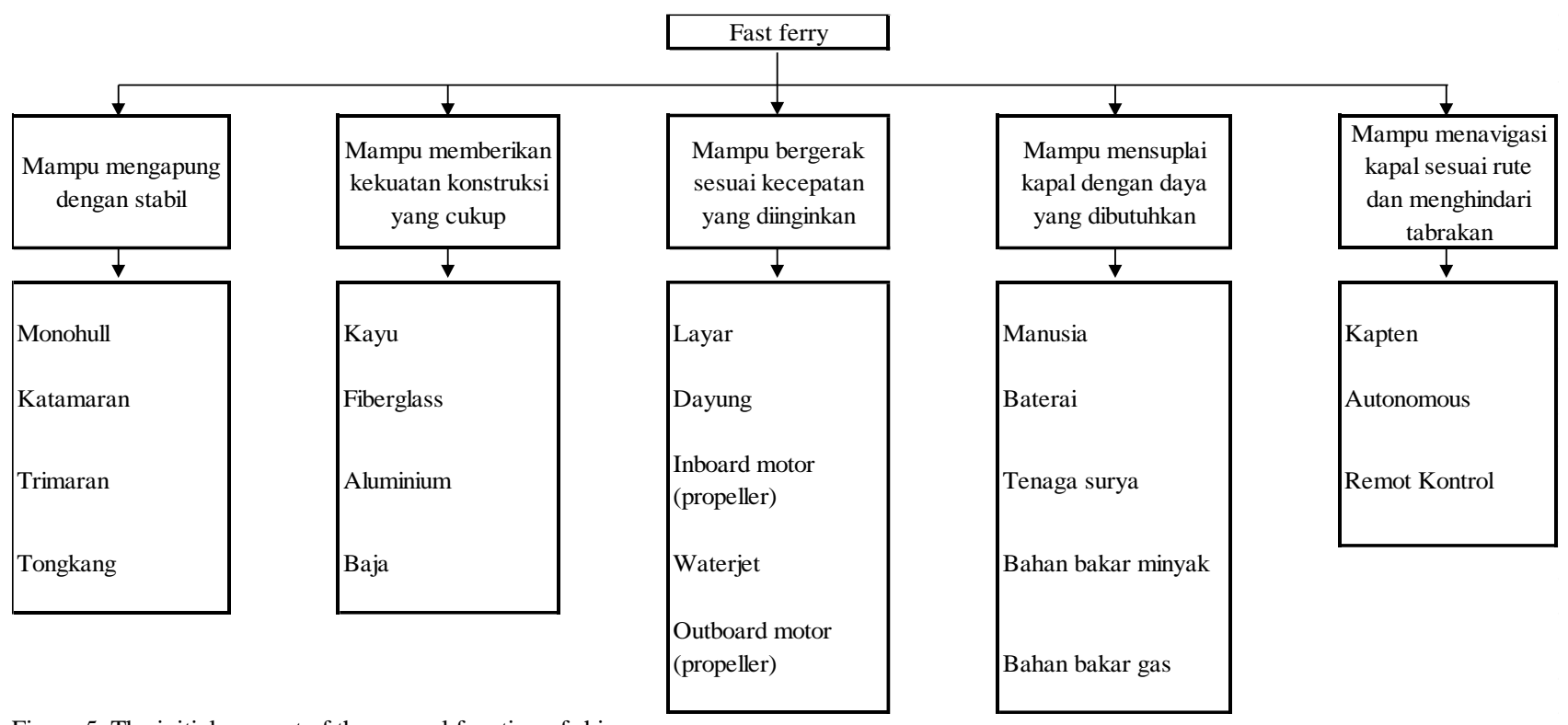

Figure 5. The initial concept of the general function of ship.

Table 4.

Existing vessel data from Damen, Incat and Austal Shipyards

\begin{tabular}{|c|c|c|c|c|c|c|c|c|c|}
\hline \multirow{2}{*}{$\frac{\mathrm{No}}{1}$} & \multirow{2}{*}{\begin{tabular}{l}
\multicolumn{1}{c}{ Main Particular } \\
Ship Name
\end{tabular}} & \multicolumn{2}{|c|}{ Damen Series } & \multirow[b]{2}{*}{$\begin{array}{l}\text { Fast Ferry } \\
4010\end{array}$} & \multicolumn{4}{|c|}{ Austal Series } & \multirow{2}{*}{$\begin{array}{l}\text { Incat } \\
\text { Hull } 090\end{array}$} \\
\hline & & $\begin{array}{l}\text { Fast Ferry } \\
36.09\end{array}$ & $\begin{array}{l}\text { Fast Ferry } \\
4009\end{array}$ & & $\begin{array}{l}\text { Fast Ferry } \\
4212\end{array}$ & Austal 35 & Austal 41 & Austal 45 & \\
\hline \multirow{4}{*}{2} & Principal Dimension & & & & & & & & \\
\hline & Overall Length & 36.2 & 40.2 & 40 & 42.2 & 35.2 & 41.2 & 45.24 & 36.6 \\
\hline & Breadth & 9.9 & 9.9 & 10.7 & 11.6 & 7 & 10.9 & 12.3 & 9.9 \\
\hline & Deaught & 1.6 & 1.6 & 1.5 & 1.5 & 1.2 & 2 & 2 & 1.8 \\
\hline 3 & Person On board & 394 & 450 & 450 & 450 & 150 & 413 & 452 & 409 \\
\hline \multirow{3}{*}{4} & Service Speed (knots) & $20-25$ & $20-25$ & $27-38$ & $30-40$ & $27-36$ & $28-37.5$ & $30-38$ & 28 \\
\hline & Max Speed (Knots) & 25 & 25 & 38 & 40 & 36 & 37.5 & 38 & 32 \\
\hline & $\begin{array}{l}\text { Sea Time to take } 210 \\
\mathrm{Nm}(\mathrm{Hr})\end{array}$ & 8.4 & 8.4 & 5.53 & 5.25 & 5.83 & 5.6 & 5.53 & 7.5 \\
\hline \multirow{6}{*}{5} & Machinery & & & & & & & & \\
\hline & Propelling Type & Diesel & Diesel & Diesel & Diesel & Diesel & Diesel & Diesel & Diesel \\
\hline & Number of Engine & 2 & 2 & 2 & 4 & 3 & 4 & 4 & 2 \\
\hline & Engine Power (kW) & 1081 & 1081 & 2880 & 1440 & 1080 & 1440 & 2000 & 1029 \\
\hline & Total Power $(\mathrm{kW})$ & 2162 & 2162 & 5760 & 5760 & 3240 & 5760 & 8000 & 2058 \\
\hline & Total Power (HP) & 2899 & 2899 & 7724 & 7724 & 4345 & 7724 & 10728 & 2759 \\
\hline \multirow{6}{*}{6} & Fuel Oil & & & & & & & & \\
\hline & $\begin{array}{l}\text { M/E FOC for max. } \\
\text { speed per engine } \\
\text { (gr/kW Hr) }\end{array}$ & 234 & 240 & 214 & 206 & 208 & 206 & 226 & 200 \\
\hline & $\begin{array}{l}\text { FO Consumption for } \\
\text { Main Engine (Ton) }\end{array}$ & 4 & 4 & 7 & 6 & 4 & 7 & 10 & 3 \\
\hline & $\begin{array}{l}\text { FO Consumption for } \\
\text { Main Engine (Litre) }\end{array}$ & 4,802 & 4,925 & 7,697 & 7,039 & 4,442 & 7,508 & 11,29 & 3,488 \\
\hline & $\begin{array}{l}\text { Fuel Oil Price per Litre } \\
\text { (Rp) }\end{array}$ & 15,67 & 15,67 & 15,67 & 15,67 & 15,67 & 15,67 & 15,67 & 15,67 \\
\hline & Total Fuel Cost per & 75.244 .812 & 77.174 .166 & 120.613 .989 & 110.299 .802 & 69.606 .671 & 117.653 .122 & 176.913 .042 & 54.659 .085 \\
\hline
\end{tabular}

\section{A. Mission Statement and Main Function Requirements}

In this study, the SBSD approach begins with a mission statement for fast ferry. This statement is the basis for defining relevant ship functions. The main mission in this research is to design a standard fast ferry to transport passengers for waters in the area of West Papua.

The fast ferry that will be designed primarily to accommodate mining company employees and tourists in the West Papua area must have convenient facilities. This is determined so as not to disrupt the existing economic sector of sea transportation, as well as to target high-class passengers who need fast and convenient sea transportation at affordable costs.
This mission reflects what is the focus of the design process and what aspects are a mandatory part of the outcome. Then the main function is determined based on the mission statement for the fast ferry. After the main function is set, the concepts that make it possible to fulfill the main function are considered. The main function requirements for fast ferry are as follows.

1) Able to provide high level of passenger comfort

2) Able to carry a minimum of 100 passengers

3) Able to reach a maximum speed of 40 knots

4) Able to transport all types of pedestrians including wheelchair users,

Once established, the main functional requirements are further analyzed in functional analysis [4] and further 
The $6^{\text {th }}$ International Seminar on Science and Technology (ISST) 2020

July $25^{\text {th }}, 2020$, Institut Teknologi Sepuluh Nopember, Surabaya, Indonesia

\begin{tabular}{|c|c|c|c|c|}
\hline Subfunction & 1 & 2 & 3 & 4 \\
\hline Hull & Monohull & Cat: & Trimaran & Barge \\
\hline Material & & & Steel & \\
\hline Propulsion & $\begin{array}{l}\text { Inboard } \\
\text { motor } \\
\text { (Propeller) }\end{array}$ & & $\begin{array}{l}\text { Outboard } \\
\text { motor } \\
\text { (propeller) }\end{array}$ & \\
\hline Source & & & Fuel oil & \\
\hline Control & Captain & $\begin{array}{l}\text { Remote } \\
\text { control }\end{array}$ & & \\
\hline
\end{tabular}

\begin{tabular}{|c|c|c|c|c|}
\hline \multicolumn{5}{|c|}{ (a) First round } \\
\hline Subfunction & 1 & 2 & 3 & 4 \\
\hline Hull & Monohull & Catar & Trimaran & Barge \\
\hline Material & Fib & & Steel & \\
\hline Propulsion & $\begin{array}{l}\text { Inboard } \\
\text { motor } \\
\text { (propeller) }\end{array}$ & & $\begin{array}{l}\text { Outboard } \\
\text { motor } \\
\text { (propeller) }\end{array}$ & \\
\hline Source & Batte & & Fuel oil & \\
\hline Control & Captain & $\begin{array}{l}\text { Remote } \\
\text { control }\end{array}$ & & \\
\hline
\end{tabular}

\begin{tabular}{|c|c|c|c|c|}
\hline \multicolumn{5}{|c|}{ (b) Second round } \\
\hline Subfunction & 1 & 2 & 3 & 4 \\
\hline Hull & Monohull & Cata & Trimaran & Barge \\
\hline Material & Fiberglass & Aluminium & Steel & \\
\hline Propulsion & $\begin{array}{c}\text { Inboard } \\
\text { motor } \\
\text { (propeller) }\end{array}$ & et & $\begin{array}{l}\text { Outboard } \\
\text { motor } \\
\text { (propeller) }\end{array}$ & \\
\hline Source & Battery & Solar c & Fuel oil & \\
\hline Control & Captain & $\begin{array}{l}\text { Remote } \\
\text { control }\end{array}$ & & \\
\hline
\end{tabular}

(c) Third round

Figure 6. The concepts of elimination of the first round (a), second (b), and third (c) in morphological combination.

converted into input data relevant to the design process. The input thus consists of requests and preferences for ship operations, based on functional requirements. Next is to determine the required vessel capacity. This is achieved by applying input in parametric exploration that will form the main dimensions while meeting capacity requirements. After the main dimensions are determined. It is possible to carry out this process on more than one design simultaneously. In this way, various alternatives can be compared at a more detailed level than when using a traditional design spiral.

\section{B. General Functions of Ship}

The mission statement for this study was used as a basis for determining the sub-function. Basically, the ship has some general functions that must be owned. From these general functions then proceed with brainstorming sessions to make
Table 5.

Remaining concept of function requirements after elimination 3

\begin{tabular}{ccccc}
\hline \hline Hull & Material & Propulsion & Resource & Control \\
\hline Monohull & Aluminum & Waterjet & BBM & Captain \\
Catamaran & Aluminum & Waterjet & BBM & Captain \\
\hline \hline
\end{tabular}

Table 6.

Alternative ranking of hull shape

\begin{tabular}{llll}
\hline \hline \multicolumn{1}{c}{ Comparison Criteria } & $\begin{array}{c}\text { Maximum } \\
\text { weight }\end{array}$ & Monohull & Catamaran \\
\hline $\begin{array}{l}\text { Load Capacity } \\
\text { - Deck area }\end{array}$ & 7.5 & 6 & 7.5 \\
- volume & 1.5 & 1.5 & 0 \\
\hline $\begin{array}{l}\text { Passenger Comfort } \\
\text { - Motion (MSI) }\end{array}$ & 10 & 8 & 4 \\
- noise and vibration & 2.5 & 2.5 & 1 \\
Operational Ability & & & \\
- maneuver & 10 & 8 & 10 \\
- Doking & 7.5 & 3.33 & 6.67 \\
- Course keeping & 10 & 4 & 8 \\
- Speed loss due to sea & 10 & 6.7 & 5.3 \\
state & & & \\
\hline Safety & 0 & 0 & 0 \\
- Trim & 0 & 0 & 0 \\
- Intact stability & 0 & 0 & 0 \\
- Damage stability & & & \\
Other attributes & 10 & 10 & 10 \\
- aesthetics & 10 & 5 & 10 \\
- Machinery redundancy & 10 & 55.03 & 63.47 \\
\hline Total Weight & 79 & $69.66 \%$ & $80.34 \%$ \\
\hline Percentage & $100 \%$ & & \\
\hline \hline
\end{tabular}

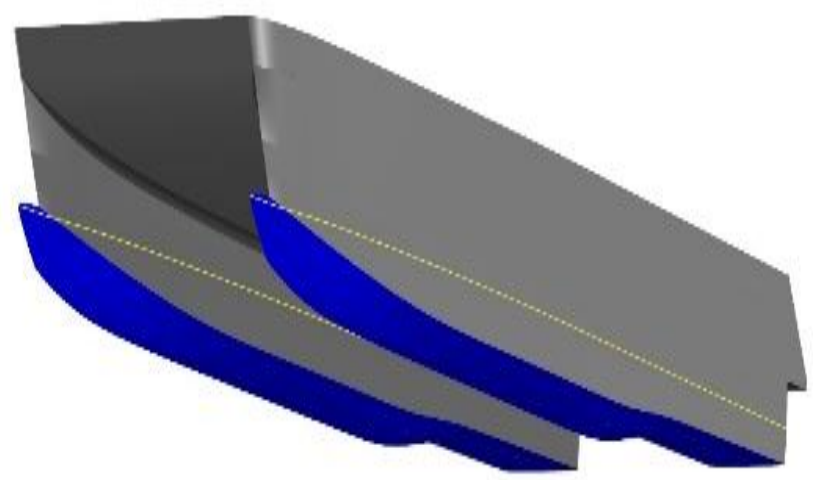

Figure 7. Perspective view of hull.

variations of each possible definition of concepts that meet these functional requirements. The results of this session are illustrated in Figure 5.

In this study, the concept will be evaluated in three screening. First, concepts that are deemed unacceptable or unworthy are eliminated before further evaluation. Then, the remaining concepts are then compared based on qualitative values and feasibility considerations. Finally, the initial design concept is determined based on the remaining concepts.

\section{Existing Vessels as Main Reference}

After the mission and main functions are set, then look for data on various types of existing fast ferry and choose 1 fast ferry that will be used as the main reference for the hull shape and initial size of this fast ferry study. The fast ferry data that is summarized can be seen inTable 4. Based on the fast ferry data that has been collected, Damen Fast Ferry 4212, Incat Hull 090, and Austal 45 are fast ferry designs that can meet the main function requirements. However, in terms of fuel 


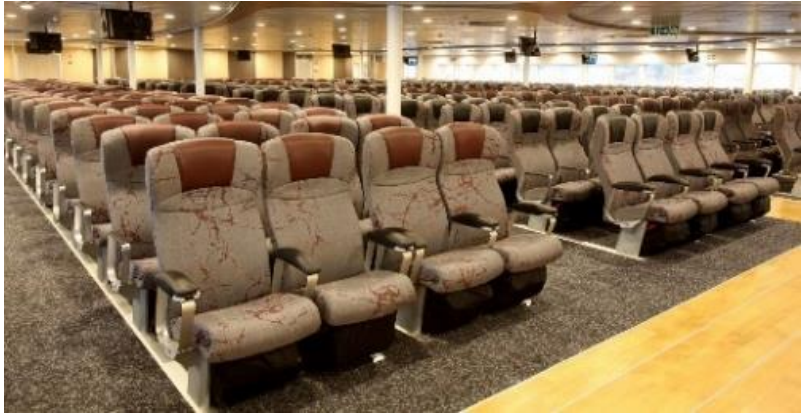

(a) Passangers seat
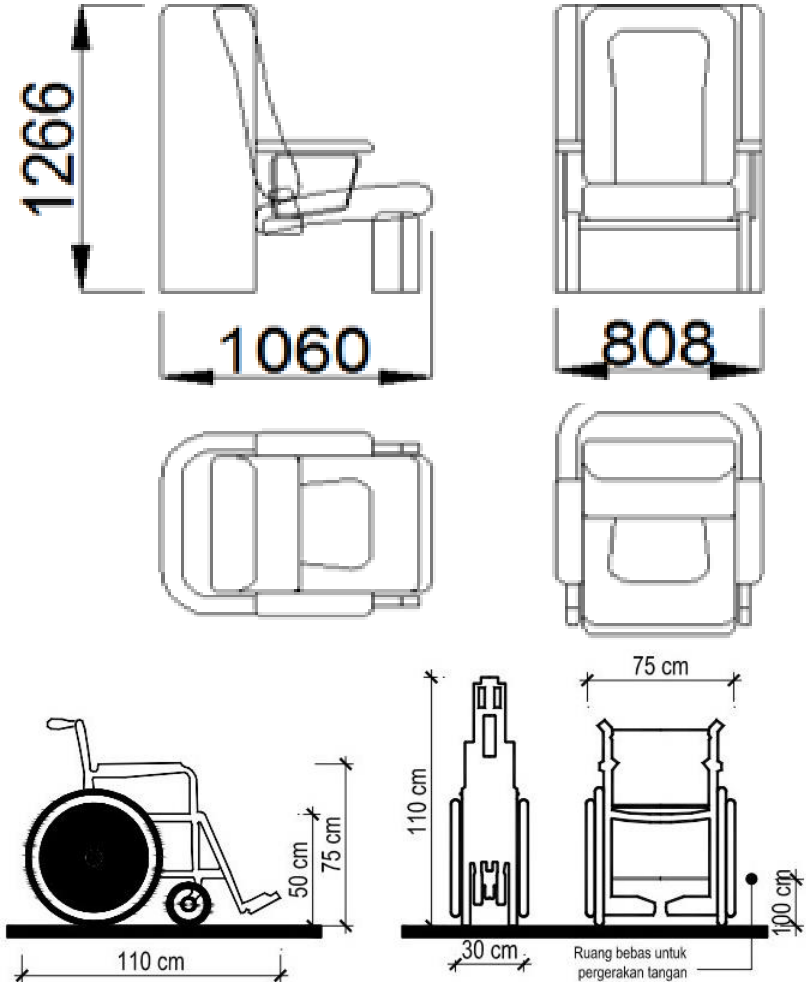

(b) Wheelchair

Figure 8. Passangers seat (a) and Passangers seat (b).

costs, Damen Fast Ferry 4212 has lower fuel costs compared to Austal 45. Even though Damen Fast Ferry 4212 and Austal 45 can carry the same number of passengers, Damen Fast Ferry 4212 can sail at speeds higher than Austal and results in lower fuel consumption costs. This shows that Damen Fast Ferry 4212 has a better hull shape than Austal 45.

Therefore, Damen Fast Ferry 4212 is used as an aircraft carrier or the main reference for designing fast ferry.

\section{RESULT AND DISCUSSION}

\section{A. Analysis of Function Requirements}

In this study, the concept will be evaluated in three screening. First, concepts that are deemed unacceptable or unworthy are eliminated before further evaluation. Then, the remaining concepts are then compared based on qualitative values and feasibility considerations. Finally, the initial design concept is determined based on the remaining concepts. Initial design concept can be seen at Figure 6 .

The reasons for screening each concept can be seen in Table 2 for the screening of the first round, Table 3 for the

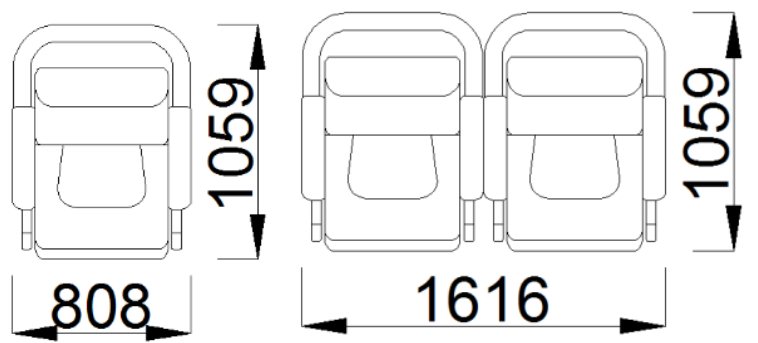

(A) Loading condition A1 (B) Loading condition A2

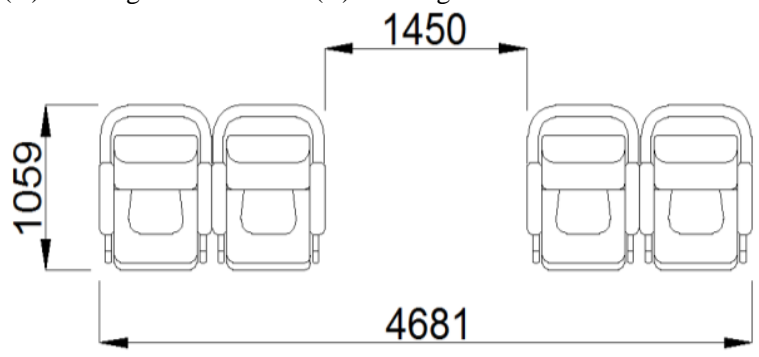

(C) Loading condition B

Figure 9. Loading condition A and B.

Table 7 .

Loading conditions

\begin{tabular}{ccl}
\hline \hline Label & $\begin{array}{c}\text { Loading } \\
\text { Conditions }\end{array}$ & \multicolumn{1}{c}{ Information } \\
\hline \multirow{2}{*}{ A } & Space per person & -1 chair with people \\
& - 2 chairs with 2 people \\
B & $\begin{array}{c}\text { Person per } \\
\text { column }\end{array}$ & $\begin{array}{l}-4 \text { seats in 1 column with access in } \\
\text { the middle }\end{array}$ \\
& People per row & -16 seats in 1 row and column with \\
and column & access in the middle \\
D & $\begin{array}{c}\text { People per row } \\
\text { and column }\end{array}$ & -100 seats \\
\hline \hline
\end{tabular}

screening of the second round, Table 1 for the screening of the third round, and Table 5 for the results of the concept that remaining.

\section{B. Determination of the Hull Shape}

The selection of the hull form is based on the ranking method as in the investigation conducted by Thomas [5]. Because the object of research in this report is fast ferry with a different operational profile, not all arguments are relevant to this study and the results cannot be used directly. In addition, "On the Great Trimaran-Catamaran Debate" by the Doctor [6] and input from Sven OleM. Nicolaysen was used to support this evaluation. The results of the assessment can be seen in Table 6 .

After all concepts are evaluated, the score is then concluded and compared with the maximum score determined by the criteria weights. The results of this weighting show that catamaran is the best concept with a score of $80.34 \%$ against $69.66 \%$ monohull. Therefore it was concluded to continue with the catamaran concept. Based on the analysis of the main function requirements, the preferred hull design for the fast ferry that will be used in this study is a symmetrical hull of catamaran made of aluminum, with two waterjet propulsion systems installed in each demihull. The hull shape in this study will be based on the Damen Fast Ferry 4212 hull form. The perspective view of the hull shown in Figure 7. 

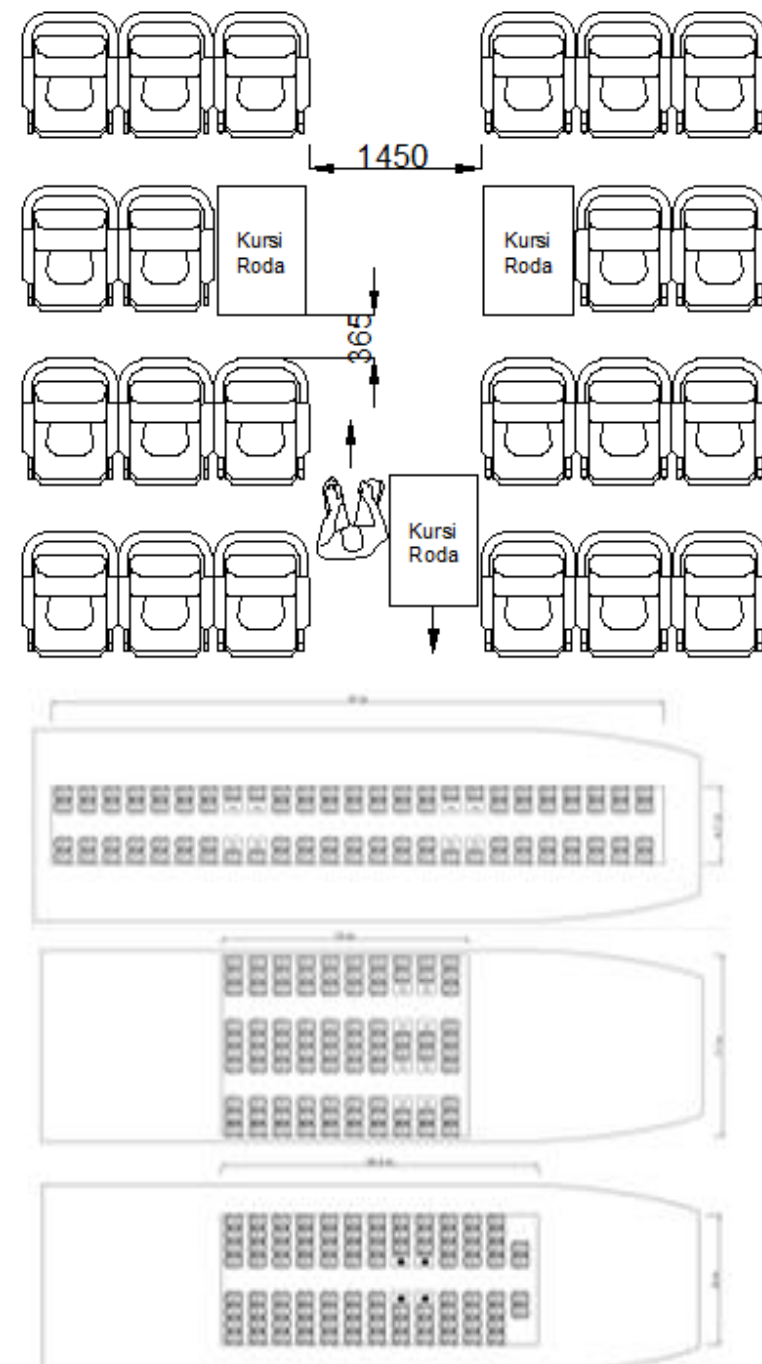

Figure 11. Loading condition C and D.

\section{Estimasi Area yang Diperlukan di Dek Utama \\ 1) Life Size Experiment}

Assumptions are given that the height on the deck must be 2.4 meters to ensure that the volume is sufficient for human height. Basically, the area on the main deck requires additional space besides the main room itself. This includes fire extinguishers, navigation rooms, backup generators, and others. This equipment is not yet listed in the SBSD space area tab. As a measure of initial dimensions, the most appropriate reference that can be used is Damen Fast Ferry Series 4212. This ship was chosen because it has a deck area that is similar to the needs of fast ferry, both the main and upper decks. The initial room requirements for passengers are determined using Sintef Building [7] which is considered the main deck area on the fast ferry. The loading conditions experiment with chairs is used to determine the size of the area for each different space are presented in Figure 8 (a).

Using this seat can give a better indication of the actual space restrictions and better defining passenger comfort. The room which is arranged with 4 chairs on each side is the simplest design. Because fast ferry are designed to be able to transport passengers in a wheelchair, the distance between

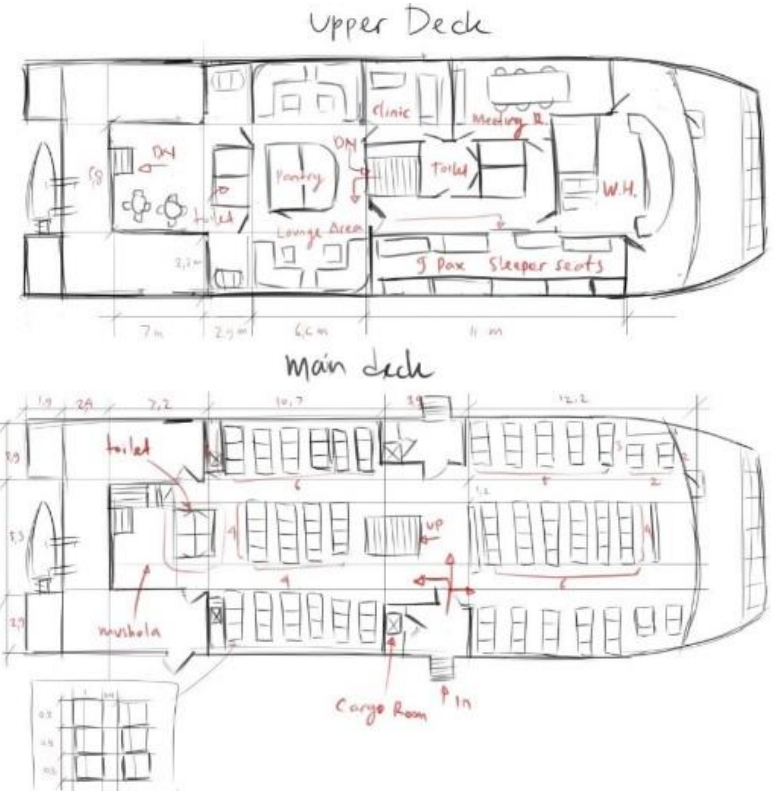

Figure 10. Sketch and and preliminary calculation of deck areas needed.

Table 8 .

The final main dimension is the fast ferry

\begin{tabular}{llll}
\hline \hline Parameter & Variable & Score & \\
\hline Length of overall & LOA & 40.387 & $\mathrm{~m}$ \\
Length of water line & LWL & 39.997 & $\mathrm{~m}$ \\
Breadth & $\mathrm{B}$ & 11.02 & $\mathrm{~m}$ \\
Breadth 1 & $\mathrm{B} 1$ & 3 & $\mathrm{~m}$ \\
Height & $\mathrm{H}$ & 4.43 & $\mathrm{~m}$ \\
Draft & $\mathrm{T}$ & 15 & $\mathrm{~m}$ \\
Displacement Full & $\Delta$ & 213.3 & Ton \\
Block coefficient & $\mathrm{CB}$ & 0.571 & \\
& & & \\
\hline
\end{tabular}

seats in the center of the seat column will be adjusted to the size of the wheelchair. This will also provide good functionality because it makes it easy for wheelchairs to move across the room. The size of the wheelchair used is as shown Figure 8 (b), so this seat arrangement is illustrated in Figure 11 The loading conditions under test are presented in Table 7. Loading condition A and B can see at Figure 9.

The loading condition $\mathrm{C}$ includes 16 seats in 1 row and column with access in the middle and adds a wheelchair between them. The illustration can illustrate that one wheelchair placed between chairs does not cause problems in terms of space for access. There is space between the chair and the wheelchair for moving people so that the flow of passengers will not be hampered if there are wheelchairs and pedestrians that overtake. To facilitate evacuation in an emergency, wheelchairs will be placed in the blood closest to the gangway and the ship's entrance and exit.

Full loading conditions for 100 passengers including wheelchairs are tested to determine how practical the design mentioned above is. The loading conditions D include several variations for 100 seats including wheelchairs with access roads in the center. Limitation of size in the arrangement of this room is the length and width of the ship. Fast ferry has dimensions of $42.2 \times 11.6$ meters. In this study, 3 variations of room arrangement were made for 100 passengers. The first variation is to use a maximum limit of 42.2 meters in length, 
The $6^{\text {th }}$ International Seminar on Science and Technology (ISST) 2020

July $25^{\text {th }}$, 2020, Institut Teknologi Sepuluh Nopember, Surabaya, Indonesia

Table 9.

Area and volume of load area

\begin{tabular}{lccccc}
\hline \hline $\begin{array}{c}\text { Load } \\
\text { category }\end{array}$ & total & $\begin{array}{c}\text { Weight } \\
\text { per unit } \\
\mathrm{kg}\end{array}$ & $\begin{array}{c}\text { Area per unit } \\
\mathrm{m} 2\end{array}$ & $\begin{array}{c}\text { High } \\
\mathrm{m}\end{array}$ & $\begin{array}{c}\text { Unit } \\
\text { volume } \\
\mathrm{m} 3\end{array}$ \\
\hline Crew & 13 & 85 & 0.33 & 2.4 & 0.79 \\
Passenger & 100 & 85 & 0.33 & 2.4 & 0.79 \\
Goods & 100 & 20 & 0.07 & 2.4 & 0.17 \\
Provision & 100 & 5 & 0.12 & 2.4 & 0.29 \\
\hline Total & 213 & 12105 & 56.29 & & 135.10 \\
\hline \hline
\end{tabular}

Table 10.

The area and volume of the passenger accommodation room area

\begin{tabular}{lccccc}
\hline \hline \multicolumn{1}{c}{ Name } & total & $\begin{array}{c}\text { area } \\
\mathrm{m} 2\end{array}$ & $\begin{array}{c}\text { High } \\
\mathrm{m}\end{array}$ & $\begin{array}{c}\text { Total Area } \\
\mathrm{m} 2\end{array}$ & $\begin{array}{c}\text { Volume } \\
\mathrm{m} 3\end{array}$ \\
\hline $\begin{array}{l}\text { Passenger seats } \\
\text { \& spaces }\end{array}$ & 100 & 1,212 & 2.4 & 121.2 & 290.88 \\
$\begin{array}{l}\text { Gangway } \\
\text { Sub-Total }\end{array}$ & 1 & & 2.4 & 43.8 & 105.12 \\
\hline \hline
\end{tabular}

Table 11.

The area and volume of the crew's accommodation area

\begin{tabular}{llllll}
\hline \hline \multicolumn{1}{c}{ Name } & total & $\begin{array}{l}\text { Area } \\
\mathrm{m} 2\end{array}$ & $\begin{array}{l}\text { High } \\
\mathrm{m}\end{array}$ & $\begin{array}{l}\text { Total Area } \\
\mathrm{m} 2\end{array}$ & $\begin{array}{l}\text { Volume } \\
\mathrm{m} 3\end{array}$ \\
\hline $\begin{array}{l}\text { Crew Room } \\
\begin{array}{l}\text { Crew } \\
\text { entertainment }\end{array}\end{array}$ & 5 & 9 & 2.4 & 45 & 108 \\
\hline Sub-Total & 9 & 2.4 & 9 & 21.6 \\
\hline \hline
\end{tabular}

Table 12.

Area and volume of facility space

\begin{tabular}{|c|c|c|c|c|c|}
\hline Name & total & $\begin{array}{l}\text { Area } \\
\mathrm{m} 2\end{array}$ & $\begin{array}{l}\text { High } \\
\mathrm{m}\end{array}$ & $\begin{array}{l}\text { Total Area } \\
\mathrm{m} 2\end{array}$ & $\begin{array}{l}\text { Volume } \\
\text { m3 }\end{array}$ \\
\hline Bathroom & 8 & 1.6 & 2.4 & 12.8 & 30.72 \\
\hline $\begin{array}{l}\text { Lounge Chair } \\
\text { (set) }\end{array}$ & 4 & 14.3 & 2.4 & 57.2 & 137.28 \\
\hline $\begin{array}{l}\text { Standing } \\
\text { lounge area }\end{array}$ & 1 & 20 & 2.4 & 20 & 48 \\
\hline Pantry & 1 & 10.56 & 2.4 & 10.56 & 25,344 \\
\hline $\begin{array}{l}\text { Lounge chairs } \\
\text { on the outside } \\
\text { deck }\end{array}$ & 20 & 2 & 2.4 & 40 & 96 \\
\hline Mosque & 1 & 12 & 2.4 & 12 & 28.8 \\
\hline Clinic & 1 & 7.5 & 2.4 & 7.5 & 18 \\
\hline Sub-Total & & & $\mathrm{m} 2 / \mathrm{pax}$ & 160.06 & 384,144 \\
\hline \multicolumn{4}{|c|}{ Total $+10 \%$ margin } & 478.89 & 1149,302 \\
\hline
\end{tabular}

the second is with a maximum width limit of 11.6 meters, and the third is less than 42.2 meters in length and 11.6 meters in width. These variations can be seen in Figure 11.

In this design, the main ship is expected to accommodate all passengers and facilities. However, not only the passenger room and passenger facilities will be located on the main deck. Various ship equipment that supports operations will also be located on the main deck such as generators, fire fighting equipment, and safety equipment. Thus, to accommodate all of it is expected that the entire main deck can be used so as to maximize the area that can be used to accommodate it all. Based on the 3 variations above, the first variation is eliminated because the room arrangement is inefficient. With this arrangement, it will take up a lot of space that should be used for another room. Furthermore, variations in room arrangement number 3 are eliminated because with the remaining space on the side will dispose of the area that was originally maximized to accommodate the
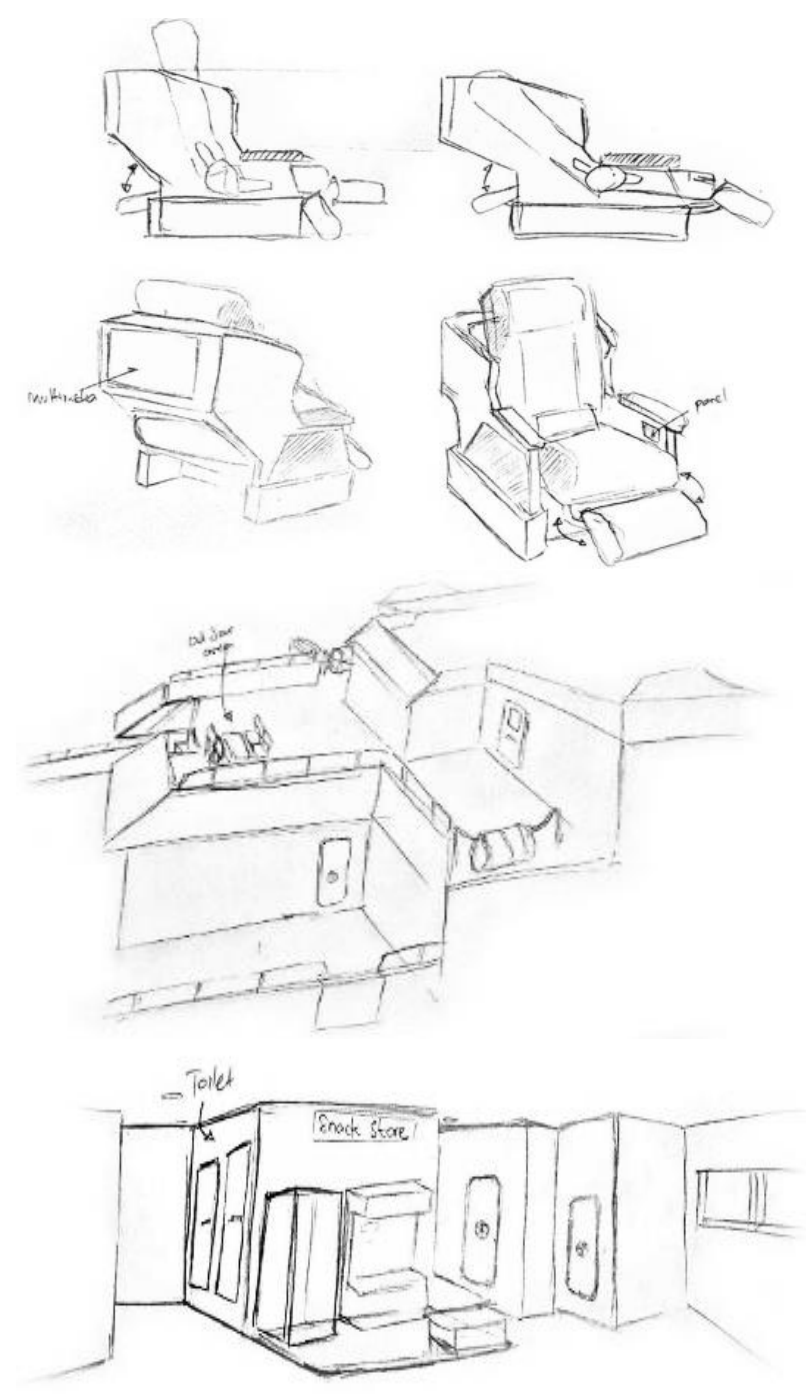

Figure 12. Sketch passenger seat balcony behind fast ferry and lounge.

equipment. So that spatial variation number 2 was chosen for further design in this study.

In variation 2 of spatial planning, several decisions were made about ship design. Seats will be placed up to the wall of the ship to ensure maximum use of the main deck area. The minimum deck area needed to accommodate all loads is based on calculations onTable 9-Table 12 is around 478.89 square meters. Based on the above considerations, a general plan sketch was made to accommodate all the needs on board for the accommodation space that can be seen at Figure 10.

\section{2) Model Size Experiment}

The purpose of this experiment is to determine the appropriate volume dimensions of the passenger space and how passenger placement must be arranged. Because there will be many possibilities for unlimited loading conditions, it is not possible to test them all. Therefore, the conditions that are considered the most relevant and most likely to occur are used as the focus. After that, the main dimensions of the ship will be used. As a first step, a sketch of the arrangement was made to ensure all the required volume, area and large objects would enter the ship. The most critical problem in this study is the capacity and ability of the ship to accommodate all 
The $6^{\text {th }}$ International Seminar on Science and Technology (ISST) 2020

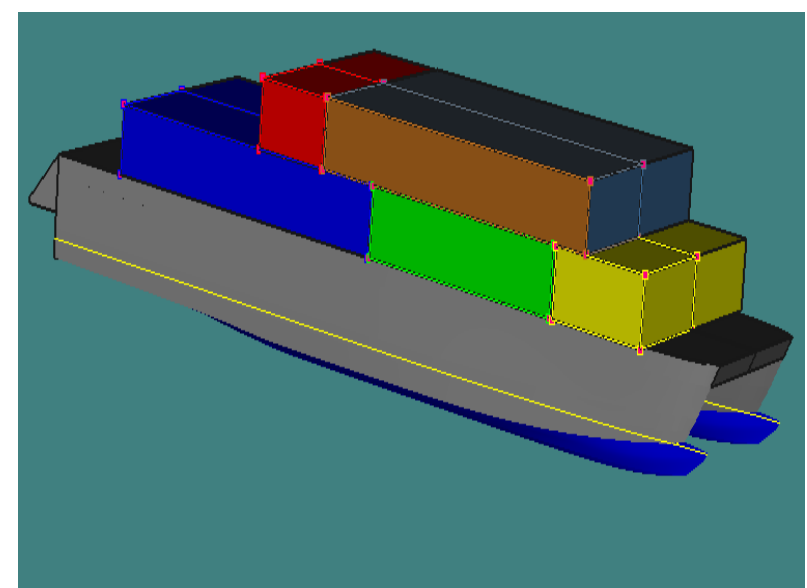

Figure 13. Sketch 3D volume for rooms on fast ferry.
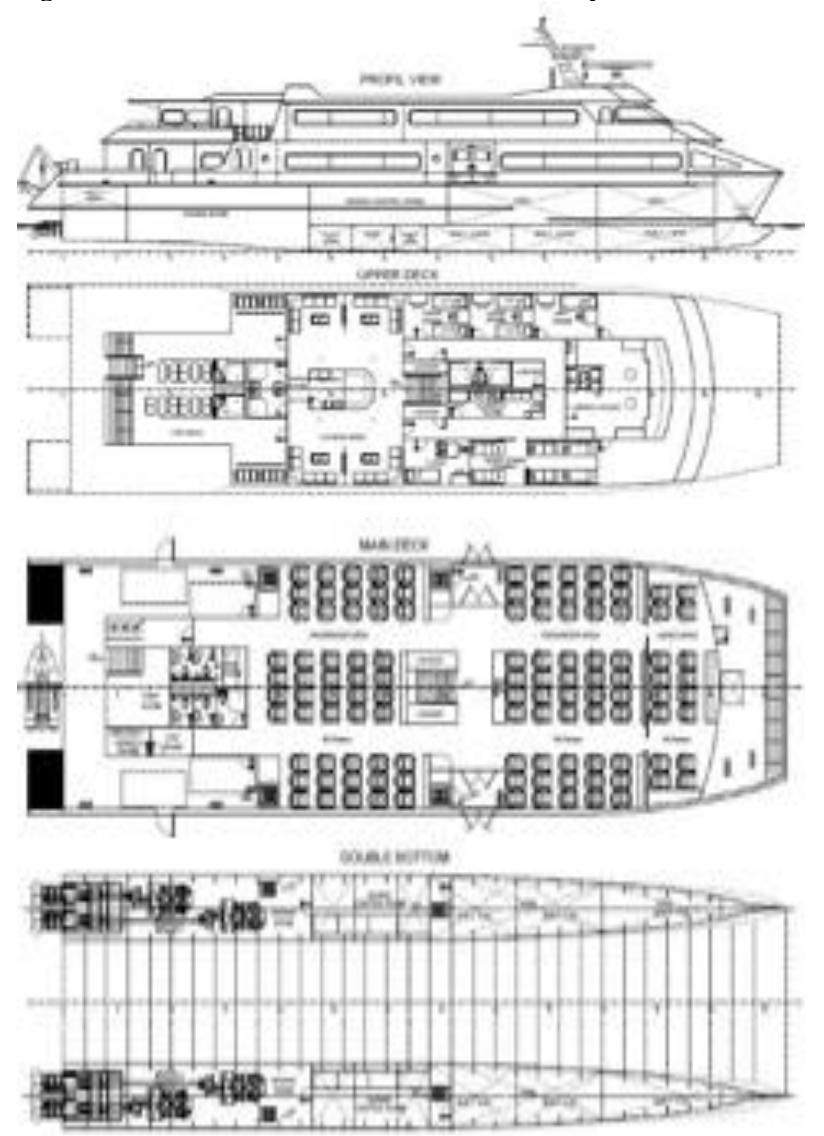

Figure 14. General Arrangement of fast ferry.

passengers with facilities that are very comfortable to rest during the trip. Other factors which are also important in providing passenger comfort are the availability of recreational facilities both on the balcony and in the lounge. An initial sketch of the balcony and lounge design is given at Figure 13. After determining the area and volume of each main ship space, a 3D sketch will be made to ensure that the entire main space can be accommodated properly on the hull as in Figure 12.

All volumes are defined using square shaped space. In the calculation, a small volume deviation in the SBSD template will occur like a passenger room access road that is not counted in the calculation. The minimum volume required to accommodate all loads based on rough calculations is around
1149,302 cubic meters with the distribution as in Figure 13.

The initial main dimensions are then continued to create a hull shape model in 3D modeling software. The main dimensions of fast ferry are based on the results of the area and volume calculations given to Table 8 . The shape of the hull in this study will be based on the Damen Fast Ferry 4212 hull. It also includes the layout of the space inside the hull. The main dimensions of Damen Fast Ferry 4212 are then adjusted to be applied to fast ferry. Based on the initial calculation results used, the efficient length (LOA) and beam (B) for fast ferry are approximately 42.2 and 11.6 meters, respectively. While the height $(\mathrm{H})$ and draft $(\mathrm{T})$ are 3.8 and 1.5 meters. This initial dimension is then analyzed for ratio so that the ship has good hydrodynamic capabilities.

\section{General Arrangement}

In this section, will explain about General Arrangement of fast feery. General Arangement of fast ferry can be seen at Figure 14.

\section{CONCLUSION}

A a fast ferry design study has been carried out by taking periran locations in the West Papua Region where this region has the most dominant economic center in the tourism sector and mining companies scattered around the City of Sorong and in the Bintuni Bay area. For inter-regional transportation, the main transportation uses air and land vehicles. To go to other areas which are located quite far away, you have to use small planes and helicopters which are quite expensive. While for land routes, it will require a much longer time due to difficult terrain. To reduce costs and cut travel time, the idea emerged to transport passengers from Sorong City to other coastal locations by fast ferry. The advantages offered by the use of fast ferry compared to airplanes are lower costs with relatively the same or more payloads, and can reach directly to coastal residential areas only by approaching the waters of the area. In addition, the advantages offered by the use of fast ferry compared to land vehicles are faster times with relatively the same or more loads.

The fast ferry design study method in this study uses the System Based Ship Design (SBSD) method. This method uses a strategy to reduce the number of loops to find the best concept by giving greater emphasis to the analysis of functions which include being able to provide high-level passenger comfort, being able to carry at least 100 passengers, being able to reach a maximum speed of 40 knots, and being able to transport all types of pedestrians including wheelchair users. Based on this, a Damen Fast Ferry 4212 reference ship was chosen for its initial primary size.

The output of the main function requirements are the main dimensions determined by using the life size experiment and the test model experiment based on the required area and volume. Various alternatives continue to be evaluated against the relevant framework conditions. Fast ferry have the main dimensions of length of $40,387 \mathrm{~m}$, breadth of 11.02 meters, and draft with 1.5 meters. It is propelled by water jet propulsion and aluminium material applied. 
The $6^{\text {th }}$ International Seminar on Science and Technology (ISST) 2020

July $25^{\text {th }}, 2020$, Institut Teknologi Sepuluh Nopember, Surabaya, Indonesia

\section{REFERENCES}

[1] Austal, “ Austal Confirms Seven Fast Ferries Ordered For The Venetian Macao Resort Development,”. Austal [Online]. Available: https://austal.com/news/austal-confirms-seven-fast-ferries-orderedvenetian-macao-resort-development [Accessed: 24-Jul-2020]

[2] Damen, "High Speed Ferry on Stock,". Damen [Online]. Available: https://products.damen.com/en/ranges/fast-ferry/damen-fast-ferry4212 [Accessed: 24-Jul-2020]

[3] Erikstad. S. O, and Levander, K. (2012). System based design of offshore support vessels. Available: https://www.researchgate.net/profile/

Stein_Erikstad/publication/276958126_System_Based_Design_of_Of fshore_Support_Vessels/links/555c946008ae8c0cab2a60b3.pdf.[Acce ssed: 3-Jun-2020]
[4] Vestbøstad, Øyvind, " System Based Ship Design for Offshore Vessels," Norwegian University of Science and Technology, 2011.

[5] Havdal. Gina, Heggelund. Christina Torjussen, Larssen, Charlotte Hjelmseth, " Design of a Small Autonomous Passanger Ferry, "Norwegian University of Science and Technology, 2017.

[6] Jakobsen, K, "Produktutvikling," 1990.

[7] G. Thomas, P. Tomic, and A. Tuite, "High-Speed Catamaran or Monohull? How do you choose?," presented at the 2nd Int.Conf. on High Performance Marine Vehicles, Australia, 2006.

[8] Doctors. L. J. (2017). On the great trimaran-catamaran debate. http://mararchief.tudelft.nl/file/37021/. .[Accessed: 5-Jun-2020]

[9] Sintef Byggforsk, . (2005). 320.100 menneskers rekkevidde og plassbehov.https://bks.byggforsk.no/DocumentView.aspx?sectionId= 2\&doc Numbe r=320100. .[Accessed: 7-Jun-2020] 